\title{
TOXIC EFFECT OF PHARMACEUTICALS WITH REFERENCE TO OXYTETRACYCLINE
}

\author{
MADHU SHARMA*
}

Department of Fisheries, COVAS, CSKHPKV, Palampur, Himachal Pradesh, India. Email: madhu.srma@gmail.com

\author{
Received: 02 October 2019, Revised and Accepted: 24 November 2020
}

\begin{abstract}
Manufacturing and release of pharmaceuticals are increasing in different countries of the world especially in developing countries. The discharge from wastewater plant contains a wide range of classes of pharmaceuticals. Rapidly growing economy, aquaculture, and livestock industry has led to increased incidences of diseases and has increased the release of pharmaceuticals into natural environment which is affecting the biodiversity of hotspots adversely. This review mainly focuses on antibiotic oxytetracycline, its use, structure, occurrence in aquatic environments and other environmental compartments, lastly an overview of toxicity to fish is provided. The threats posed by these pharmaceuticals are evident from the studies showing their toxic effect on different aquatic organisms.
\end{abstract}

Keywords: Pharmaceuticals, Oxytetracycline, Toxicity.

(c) 2021 The Authors. Published by Innovare Academic Sciences Pvt Ltd. This is an open access article under the CC BY license (http://creativecommons.org/ licenses/by/4.0/) DOI: http://dx.doi.org/10.22159/ajpcr.2021v14i1.39907. Journal homepage: https://innovareacademics.in/journals/index.php/ajpcr

\section{INTRODUCTION}

Concern about the effects of pharmaceuticals on the aquatic environment has been increasing in the last years. Antibiotics are of particular concern since they are extensively used in aquaculture where they may be applied directly into the water or be incorporated in the food [1]. In the aquatic ecosystem pharmaceuticals may cause deleterious effects on the aquatic organisms accidentally exposed to them. Antimicrobial agents are extensively used in human and veterinary medicine and in aquaculture. Worldwide estimation of antimicrobial agent's consumption lies between 100,000 and 200,000 tons/year [2]. According to the European Federation of Animal Health report, in the year 1999, 65\% of antimicrobials were used in human medicine [3]. In the survey by the European medical agency, the sales of veterinary antimicrobial agents were compared among European countries, resulting from 18 to $188 \mathrm{mg} \mathrm{kg}^{-1}$ of antimicrobials per kilogram of biomass of food producing animals [4].

Between 2000 and 2015 antibiotic consumption in 76 countries around the world, expressed in defined daily doses (DDDs), increased 65\% and, in 2015, reached 42 billion DDDs. Among high-income countries, the leading consumers of antibiotics in 2015 were the United States, France, and Italy. Leading consumers of antibiotics between lowand middle-income countries were India, China, and Pakistan [5]. Worldwide antibiotic use is expected to be $200 \%$ higher by 2030 than in 2015 , with the greatest increase coming from low- and middle-income countries. Among antibiotics, tetracyclines were the most commonly used, followed by sulfonamides and macrolides that accounted for approximately $90 \%$ of the total antibiotics used in the UK and more than 50\% in Korea and Denmark [6]. There are significant differences in trends in the antibiotic consumption in European countries. According to the Antimicrobial Consumption Annual Epidemiological Report for 2016 published by the European Center for Disease Prevention and Control (ECDC), a statistically significant trend of increasing antibiotics usage was observed for Greece and Spain from 2012 to 2016, while over the same time period a statistically significant decreasing antibiotics usage trends were observed for Finland, Luxembourg, Norway, and Sweden. The most prescribed categories of antibiotics in the United States and the European Union are penicillins, macrolides, cephalosporins, and fluoroquinolones (CDC Centers for Disease, 2015). More detailed information on the consumption of various antibiotics in some EU and US countries has been provided by Singer et al. [7].
In Indian economy, the pharmaceutical industries are one of the fastest growing segments. Nowadays, India is the world's leading exporter of generic drugs, which account for $75 \%$ of its market by volume [8]. Production of pharmaceuticals is rising at $14 \%$ per year. This may be due to excise duty free zone for pharmaceutical manufacturing done by the Central and State Governments of India leading to large scale production of pharmaceutical. Due to lack of strong and specific regulation in a country like India, pharmaceutical waste management has become a herculean task and leads to the problem of ever growing environmental pollution. The studies demonstrated that very high concentrations of antibiotics and antibiotics resistant bacteria were found in effluents from a sewage treatment plant in India. Particularly, high concentrations of terbinafine, citalopram, cetirizine, ciprofloxacin, and enoxacin were found in drinking water [9]. The main routes of antibiotics to reach in the aquatic environment are manufacturing industries, municipal effluent, ineffective sewage treatment plant, livestock, aquaculture, and agricultural activities [10].

Tetracyclines are useful against Gram-negative and Gram-positive bacteria, they were discovered in the 1940 s, and they are a group of broad-spectrum antibiotics [11]. In veterinary and agriculture, the tetracyclines are one of the most widely used classes of broad spectrum antibiotics due to their oral administration, very low cost and few side effects.

Tetracyclines are formed of a four-ring core to which various side groups are attached. At the C4 carbon, dimethylamino group present, this shows the antimicrobial activity. 4-De-dimethylamino tetracyclines (Fig. 1), also called chemically modified tetracyclines (CMTs), due to the inability of the molecule to adapt a zwitterionic form (CMTs) and lacks antimicrobial activity in vivo [12]. The lower half of the molecule is oxygen-rich and binds with both eukaryotic and prokaryotic targets, and interference with this region reduces the effectiveness of the drug [13].

Oxytetracycline (OTC) is the broad spectrum antibiotics of tetracycline group and an antibacterial agent which is used as human and veterinary medicines for prophylactic and therapeutic purposes [14]. OTC inhibits the protein synthesis that interacts with $30 \mathrm{~s}$ ribosomal unit [15]. Oxytetracycline was first isolated from the bacteria Streptomyces rimosus in 1948 from soil and $2^{\text {nd }}$ antibiotics to be discovered. OTC is used as animal and human medicine because it has low price and excellent antimicrobial activity with very less side effects [16]. 
Oxytetracycline is one of the main antibiotics used nowadays to defend bacterial disease in fish. Maximum of OTC is given to fishes through the feed, but fish have a very less absorption for OTC so $70-80 \%$ of OTC is excreted as waste material into the water [17]. It can be retained in sludge and bottom deposits of fish farms due to their lipophilic and non-degradable nature [18]. Its residue shows direct effect on fish and other consumers and has a relatively long half-life [19].

\section{CHEMICAL STRUCTURE}

Robert Woodward studied the chemical structure of the OTC (1953). From 1950-1980 several members of the tetracycline family are developed and they become very popular antibiotics in the United States [20]. OTC is in the form of hygroscopic yellow crystals and odorless. It has a bitter taste and decomposes at $180^{\circ} \mathrm{C}$. It is insoluble in chloroform and ether, slightly soluble in ethanol and soluble in water [21].

Molecular formula: $\mathrm{C}_{22} \mathrm{H}_{24} \mathrm{~N}_{2} \mathrm{O}_{9}$.

Like other tetracycline OTC is also formed of 4 core ring which contain many functional groups as seen in Fig. 2. OTC contains hydroxyl groups at C-3, C-5, C-6, C-10, C-12 position, Carbonyl group at C-1 and C-11, nitrogen atom at $\mathrm{C}-4$ position, and caboxamide group at $\mathrm{C}-2$ position of A-ring. In OTC both pharmacokinetic and antibacterial properties is influenced by the chelation with metal ions present in biological environment and food so it is a strong chelating agent [22].

\section{OCCURRENCE}

OTC is detected in soil, water bodies, in tissues of living organisms. Different studies have supported the presence of OTC in rivers, lakes, rainwater, ground water, sea, soil, and in the tissues of living organisms.

Kay [23] proved that most common antibiotics Oxytetracycline (OTC) is difficult to biodegrade. Residual OTC has been detected in different areas, for example, in British soil; the concentration of OTC was as high as $1691 \mu \mathrm{g} / \mathrm{kg}$. Wang et al. [17] observed the gathering of OTC in muscles, kidney, blood, and liver tissues of black sea bream Sparus macrocephalus and perch Lateolabras janopicus. Boxall et al. [24] illustrated the presence of OTC in animal husbandry effluents

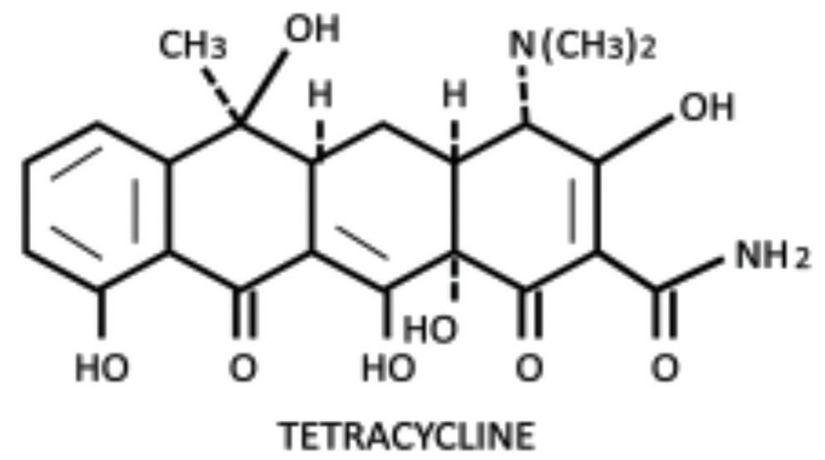

Fig. 1: Chemical structure of tetracycline<smiles>CN(C)C1C(O)=C(C(N)=O)C(=O)C2C(O)=C3C(=O)c4c(O)cccc4[C@@](C)(O)C3C(O)C21</smiles>

Fig. 2: Chemical structure of oxytetracycline
(15.133 $\mathrm{ng} \mathrm{\textrm {L } ^ { - 1 }}$ ), in wastewater (1600 $\mathrm{ng} \mathrm{L}^{-1}$ ), and in surface water (340 $\mathrm{ng} \mathrm{L}^{-1}$ ), respectively. Bjorklund et al. [25] found that OTC can cause deleterious effects because it can persist for relatively long periods in fish tissues and sediments. Olatoye et al. [26] investigated that the OTC residues in the muscle and liver sample of a total of 160 fishes collected from fish farms and restaurants. Barani et al. [27] tested the OTC residues in the body of 138 trout sample and found its presence in 87 samples between 1.43 and $101.4 \mu \mathrm{g} / \mathrm{kg}$. Baydon et al. [28] evaluated that the OTC residues in samples of fish Oblada melanura and Mullus barbatus in their natural habitat, caught in the vicinity of fish farms around Aegean Sea.

Kolpin et al. [29] conducted a study during 1999 and 2000 in 30 states, the concentration levels of oxytetracycline (OTC) ranging from 0.10 to $0.34 \mathrm{mg} / \mathrm{L}$ were found in streams. Thurman et al. [30] reported antibiotics in sewage from fish ponds, where the concentration of OTC ranged from 0.17 to $10 \mathrm{mg} / \mathrm{L}$. Bebak-Williams et al. [31] observed that the higher OTC concentration is present in re-circulating water supplies than in adjoining surface waters. Samuelsen et al. [32] concluded that the primary fate of antibiotics is to deposition in the sediments in aquatic ecosystems. They measured the concentrations of OTC in sediments ranging from 0.4 to $495 \mathrm{mg} / \mathrm{g}$. Capone et al. [33] studied the effect of OTC in non-target organisms such as clams, oysters, and crustaceans following discharge in the vicinity of aquaculture operations.

Coyne et al. [34] founded the OTC concentrations in oysters (Crassostrea gigas) and Dungeness crab, which is $<0.1 \mathrm{mg} / \mathrm{g}$, while in red rock crabs, the OTC concentration detected at levels of $0.8-3.8 \mathrm{mg} / \mathrm{g}$. In soft tissue of mollusks, the concentration of OTC residues is up to $10.2 \mathrm{mg} / \mathrm{g}$.

TC has been classified among the antibiotics frequently detected in sewage, domestic wastewaters, surface and groundwater resources, drinking water, and sludge (Panguha et al. 2011). Tetracyclines have the highest concentrations and are most frequently reported antibiotic residues in manure $[35,36]$. The concentrations of oxytetracycline and chlortetracycline in some agricultural lands may reach extremely high levels. Previously conducted studies showed that one of the most widely used antibiotics in animals is tetracycline [37]. Concentration of tetracycline was found to be between 170 and $850 \mathrm{ng} \mathrm{L}^{-1}$ in a study conducted in the United States of America in effluent from WMWTP [38]. In natural aquatic environments, OTC has been detected at micro concentration levels $(\mu \mathrm{g} / \mathrm{L})$ in surface water, wastewater, and treated wastewater $[39,40]$. Environmental monitoring studies have reported OTC as high as $68 \mu \mathrm{g} / \mathrm{L}$ in river water in Japan [41]. Javid et al. [42] found tetracycline levels in surface and ground water at nearby of animal farms in the vicinity of Fasha-foyab-dam to vary from 5.4 to $8.1 \mathrm{mg} \mathrm{L}^{-1}$ and found a maximum concentration at Yaft-Abad sampling station and found $9.3 \mathrm{ng} \mathrm{\textrm {L } ^ { - 1 }}$, while TC concentration is found to be negligible in hospital wastewater treatment plant and the main reason TC is no longer being used among hospitalized patients. However, several studies reported their presence in coastal or estuarine marine systems $[43,44]$. Data are present in literature suggesting a long persistence of oxytetracycline in the aquatic sediments [39]. Oxytetracycline is very often detected in the marine environment $[33,36]$.

India is among the top five world market of pharmaceuticals and expected turnover by 2020 will USD 45 billion/year [45]. In spite of bulk production around $80 \%$ is consumed in India only [8]. On the other hand, sewage treatment capacity in India is far below the generated by 1.3 billion populations. Therefore, different pharmaceuticals have been detected in various environmental compartments in India. Forty-three pharmaceuticals and 13 metabolites, including psychoactives, artificial sweetener, and illicit drugs in five waste treatment plants that treat domestic sewage in India have been reported by Subedi et al. [46]. Few studies on the presence of pharmaceuticals in hospital effluents have been conducted in India and found that hospital effluents contains a much higher concentration of these as compared to sewage treatment plant [47]. Similarly, different researchers have reported the presence of different pharmaceutical in different rivers of India [46-48]. 


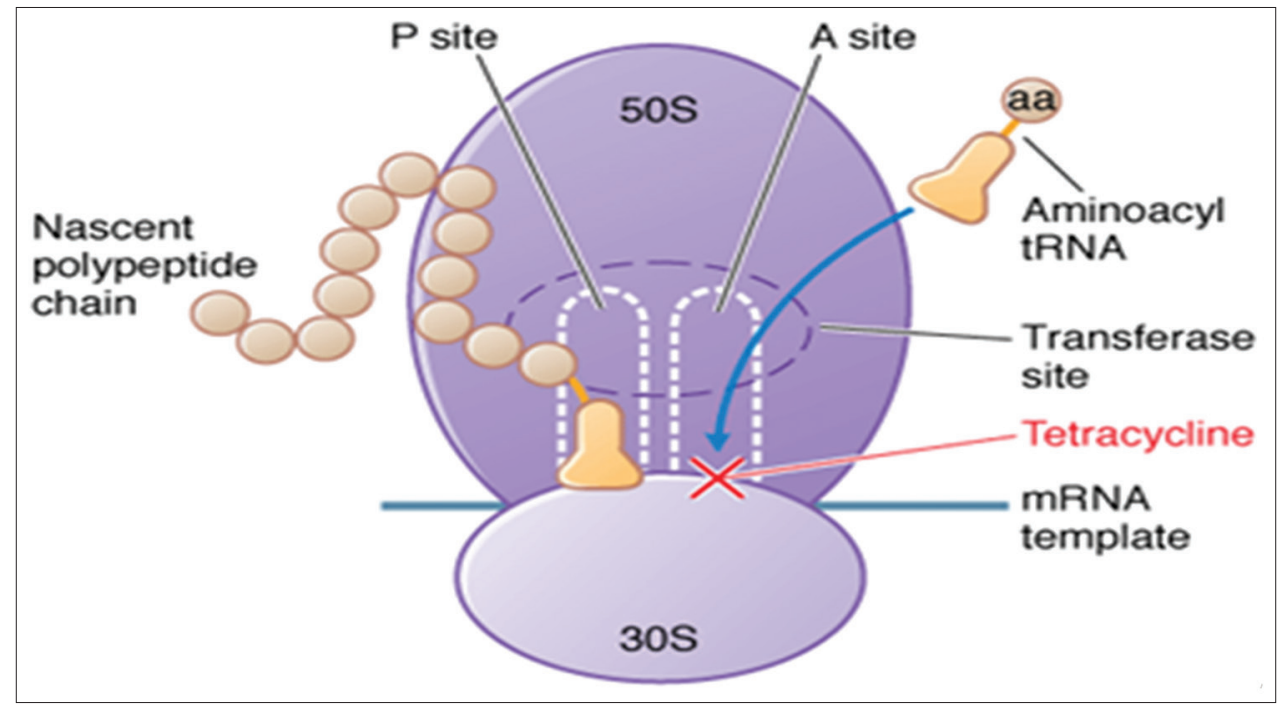

Fig. 3: Working of tetracycline as antibiotics

\section{WORKING OF TETRACYCLINES AS ANTIBIOTICS}

The survival and growth of bacterial cells are inhibited by the OTC; mostly it inhibits the production of bacterial proteins [49]. Tetracyclines also cause the outflow of genetic material and other complexes out of the cells by altering the bacterial membrane [49].

Hash et al. [50] suggested that the tetracyclines (OTC) primarily bind to the bacterial ribosome and inhibiting protein synthesis and exert their antibiotic effect. Semenkov et al. [51] studied that in bacterial ribosome (30S-50S subunit); many high-affinity binding site and low-affinity sites are present (Fig. 3). OTC gets bind with the 30S subunit and allosterically inhibit binding of the amino acyl-tRNA at the acceptor site (A-site), due to which protein synthesis ceases. Yamaguchi et al. [52] said that the use of OTC and other tetracyclines has reduced in recent decades due to the emergence of resistant strains of bacteria. Singh et al. [53] suggested that the use of OTC in aquaculture may increase the risk of transfer of antibiotic resistance to human pathogens and it became more dangerous to human.

\section{TOXICITY OF OXYTETRACYCLINE}

The excess amount of OTC causes various deleterious effects on living organisms. It gets stored in the tissues and muscle of fish and enters in to human when it is consumed by the them and shows deleterious effects on the health of human. Samanidou et al. [54] tested that the use of excessive amount of antibiotics (OTC) may lead to the presence of residual antibiotics in fish products and fish tissue.

Guardiola et al. [55] concluded that the OTC increases the cellular parameters in gilthead sea bream and interferes with humoral innate immune parameters. Hentschel et al. [56] elucidated that the side effects of long-term antibiotic like OTC use on fish can induce liver damage and nephrotoxicity. Zounkova et al. [15] reported that in aquatic ecosystems oxytetracycline may have both, the ecotoxic and genotoxic effects. Santos et al. [57] suggested that pharmaceuticals and drugs cause severe ecological disability, and they have tendency to interfere with various pathways of fish, such as Lionetto et al. [58] studied the neurotoxicity in fish and Ren et al. and Limbu et al. [59,60] studied the detoxification in fish. Micale et al. [61] visualized that the primary toxicity of antibiotics is exerted mainly at biochemical and molecular levels, later toxicity observed at higher levels of biological classification (cell, tissue, organ, individual, and population). Due to excess amount of antibiotics concentrations, the aquatic organisms undergoes in oxidative stress [62]. Several studies indicated that tetracyclines have an antioxidant activity [63]. Other studies suggested that it may be involved in reactive oxygen species formation. Khan et al. [64] have revealed that when tetracycline $\mathrm{Cu}$ (II) complex bind to DNA a methyl group is transferred by tetracycline to nitrogen base with generation of free radical. They pointed that the accumulation of abnormal proteins, lipid peroxidation products, and DNA damage (genotoxicity) all are the result of oxidative stress which occurs due to adverse environmental conditions. OTC is largely used as food additives in animal husbandry as their residues are found in several animal products such as milk, eggs, fish, or meat. Gunes et al. [19] revealed that the beekeepers use OTC against the bacterial diseases that affect honeybees, in apiculture and in the honey of treated bees OTC residues can be detected in trace levels which later pass into the body of consumers. Sara et al. [65] used $(0.0002-200 \mu \mathrm{g} / \mathrm{L})$ of erythromycin and $0.0004-400 \mu \mathrm{g} / \mathrm{L}$ of oxytetracycline on gilthead seabream (Sparus aurata) fish to study the histopathological effects in gills and liver. In both organs, several disorders such as circulatory, progressive, inflammatory, and regressive, are observed.

Botelho et al. [66] studied the genotoxic response in juvenile tilapia (O. niloticus) when exposed with $4,8,16$, and $32 \mu \mathrm{g} / \mathrm{L}$, concentration of OTC for $96 \mathrm{~h}$. Genotoxic responses shown by the fish are higher DNA damage and nuclear abnormalities. Maximum damage is seen in the fish, exposed to higher concentrations. Ren et al. [59] exposed $P$. trituberculatus larvae with $30 \mu \mathrm{g} / \mathrm{L}$ of OTC and observed DNA damage in larvae. Khan et al. and Botelho et al. $[64,66]$ observed the genotoxicity in fish $S$. aurata when exposed to OTC. Using comet assay they found that OTC has the potential to induce broken DNA strands. Genotoxicity can be an outcome of oxidative stress elicited by several pollutants. Limbu et al. [60] observed that the OTC stimulated neutrophils and macrophages in liver tissues when they exposed the 0 . niloticus with at $420 \mathrm{ng} / \mathrm{l}$ of OTC. Said et al. [67] visualized that in rodent species (guinea pig), tetracycline (OTC) is able to disturb the function of parasympathetic nervous system and can cause neuromuscular blockage and cranial nerve toxicity in humans. Rodrigues et al. and Khan et al. $[62,64]$ investigated the genotoxicity of OTC in O. mykiss, they concluded that the OTC has high affinity to bind with DNA and form tetracycline - DNA (TC-DNA) binary complexes as a result it causes change in the secondary structure of DNA-duplex. Sharma [68] found OTC cytotoxic and genotoxic in fish Cyprinus carpio.

Limbu et al. and Nazeri et al. [60,69] demonstrated that the pathways of energy metabolism can affected by the exposure of OTC in treated fish. The enhanced gluconeogenesis, inhibition of aerobic glycolysis, $\beta$-oxidation of fatty acids in hepatic tissue and suppressed lipogenesis all are the effects caused by OTC. They also observed that these effects are due to oxidative stress. Oxidative stress is generated due to the ability of OTC to increase the generation of reactive oxygen species 
(ROS) such as peroxides, oxygen ions, and free radicals. Various studies indicate that generation of ROS and nitrogen species can cause oxidative stress when erythromycin (ERY) and OTC are metabolized in tissues of various fish species, namely, S. aurata [55], O. mykiss [62,70], C. auratus [71], and D. rerio [72].

Wide range of pharmaceutical residues derived from domestic use, hospitals, ground water, sea, and estuaries. This review provides a wakeup call to the stakeholder including regulatory agencies in India to establish minimal permissible limit of pharmaceuticals in waste water to avoid its toxic effects.

\section{AUTHORS' CONTRIBUTION}

Dr. Madhu Sharma: Draft the review paper

\section{CONFLICTS OF INTEREST}

The authors declare that there are no conflicts of interest.

\section{REFERENCES}

1. Shao ZJ. Aquaculture pharmaceuticals and biologicals: Current perspectives and future possibilities. Adv Drug Deliv Rev 2001;50:229-43.

2. Wise R. Antimicrobial resistance: Priorities for action. J Antimicrob Chemother 2002;49:585-6.

3. Kümmerer K. Antibiotics in the aquatic environment--a review--Part I. Chemosphere 2009;75:417-34

4. Grave K, Torren-Edo J, Mackay D. Comparison of the sales of veterinary antibacterial agents between 10 European countries. J Antimicrob Chemother 2010;65:2037-40.

5. Klein EY, Thomas P, Boeckel V, Elena M, Pant SM, Gandra S, et al. Global increase and geographic convergence in antibiotic consumption between 2000 and 2015. Proc Natl Acad Sci 2017;115:E3463-70.

6. Kim KR, Owens G, Kwon SI, So KH, Lee DB, Ok YS. Occurrence and environmental fate of veterinary antibiotic in the terrestrial environment. Water Air Soil Pollut 2011;163:163-74.

7. Singer AC, Shaw H, Rhodes V, Hart A. Review of antimicrobial resistance in the environment and its relevance to environmental regulators. Front Microbiol 2016;7:1728.

8. Kallummal M, Bugalya K. Trends in India's Trade in Pharmaceutical Sector. New Delhi: SomeInsights; 2012. p. 1-97.

9. Fick J, Hanna SO, Derstro M, Lindberg RH, Phan C, Tysklind M, et al. Contamination of surface, ground, and drinking water from pharmaceutical production. Environ Toxicol Chem 2009;28:2522-7.

10. Burkina V, Zlabek V, Zamaratskaia G. Effects of pharmaceuticals present in aquatic environment on Phase I metabolism in fish. Environ Toxicol Pharmacol 2015;40:430-44.

11. Chopra I, Roberts MC. Tetracycline antibiotics: Mode of action, applications, molecular biology and epidemiology of bacterial resistance. Microbiol Mol Biol Rev 2001;65:232-60.

12. McNamara TF, Golub LM, D'Angelo G, Ramamurthy NS. The synthesis and characterization of non-antimicrobial chemicallymodified tetracycline (CMT) (Abstract). J Dent Res 1986;65:515.

13. Golub LM, Ramamurthy NS, McNamara TF, Greenwald RA, Rifkin BR. Tetracyclines inhibit connective tissue breakdown: New therapeutic implications for an old family of drugs. Crit Rev Oral Biol Med 1991;2:297-321.

14. Wu Y, Yue Q, Gao Y, Ren Z, Gao B. Performance of bimetallic nanoscale zero-valent iron particles for removal of oxytetracycline. J Environ Sci 2017;69:173-82.

15. Zounkova R, Klimesova Z, Nepejchalova L, Blaha L. Complex evaluation of ecotoxicity and genotoxicity of antimicrobials oxytetracycline and flumequine used in aquaculture. Environ Toxicol Chemi 2011;30:1184-9.

16. Shi ZJ, Hu HY, Shen YY, Xu JJ, Shi ML, Jin CR. Long-term effects of oxytetracycline (OTC) on the granule-based anammox: Process performance and occurrence of antibiotic resistance genes. Biochem Eng J 2017;127:110-8.

17. Wang C, Pan X, Fan Y, Chen Y, Mu W. The oxidative stress response of oxytetracycline in the ciliate Pseudocohnilembus persalinus. Environ Toxicol Pharmacol 2017;56:35-42.

18. Ambili TR, Saravanan M, Ramesh M, Abhijith DB, Poopal RK. Toxicological effects of the antibiotic oxytetracycline to an Indian major carp Labeo rohita. Arch Environ Contam Toxicol 2012;64:494-503.

19. Gunes A, Ataoglu N, Turan M, Esitken A, Quirine M. Effects of phosphate solubilising microorganisms on strawberry yield and nutrient concentrations. J Plant Nutr Soil Sci 2009;172:385-92.

20. Shales DM. An update on tetracycline. Curr Opin Investig Drugs 2007:7:167-71.

21. Moffat AC, Osselton MD, Widdop B. Clarke's analysis of drugs and poisons. In: Pharmaceuticals, Body Fluids and Postmortem Material. $4^{\text {th }}$ ed. London: Pharmaceutical Press; 2011.

22. Chartone-Souza E, Loyola TL, Rodriguez M, Menezes MA, Rey NA, Pereira-Maia EC. Synthesis and characterization of a tetracyclineplatinum (II) complex active against resistant bacteria. J Inorg Biochem 2005;99:1001-8.

23. Kay P, Blackwell PA, Boxall AB. Fate of veterinary antibiotics in a macroporous tile drained clay soil. Environ Toxicol Chem 2004;23:1136-44.

24. Boxall AB, Fogg LA, Blackwell PA, Kay P, Pemberton EJ, Croxford A. Veterinary medicines in the environment. Rev Environ Contam Toxicol 2004;180:1-91.

25. Bjorklund H, Bondestam J, Bylund G. Residues of oxytetracycline in wild fish and sediments from fish farms. Aquaculture 1990;86:359-67.

26. Olatoye IO, Basiru A. Antibiotics usage and oxytetracycline residue in African catfish (Clarias gariepinus) in Ibadan, Nigeria. World J Fish Marine Sci 2013;5:302-9.

27. Barani A, Fallah AA. Occurance of tetracycline, sulfonamides, fluoroquinolones and florefenicol in formed rainbow trout in Iran. Food Agric Immunol 2014;26:420-9.

28. Baydon E, Kaya S, Cergirgan H, Yildirim E, Yurdakok BA, Ekici H, et al. Investigation of some veterinary drugs residues in sea water, sediments and wild fishes captured around fish farm in the Aegean sea: Oxytetracycline, ivermectin and emamectin. Ankara Univ Vet Fak Derg 2015;62:171-6.

29. Kolpin DW, Furlong ET, Meyer MT, Thurman EM, Zaugg SD, Barber LB, et al. Pharmaceuticals, hormones, and other organic wastewater contaminants in U.S. streams, 1999-2000: A national reconnaissance. Environ Sci Technol 2002;36:1202-11.

30. Thurman EM, Dietze JE, Scribner EA. Occurrence of Antibiotics in Water from Fish Hatcheries. Toxic Substance Hydrology Program. Technical Report Reston, Virginia, United States: United States Geological Survey; 2003. p. 120-2.

31. Bebak-Williams J, Bullock G, Carson MC. Oxytetracycline residues in a freshwater Recirculating system. Aquaculture 2002;205:221-30.

32. Samuelsen OB, Lunestad BT, Husevdg B, Hølleland T, Ervik A. Residues of oxolinic acid in wild fauna following medication in fish farms. Dis Aquat Org 1992;12:111-9.

33. Capone DG, Weston DP, Miller V, Shoemaker C. Antibacterial residues in marine sediments and invertebrates following chemotherapy in aquaculture. Aquaculture 1996;145:55-75.

34. Coyne R, Hiney M, Smith P. Transient presence of oxytetracycline in blue mussels (Mytilus edulis) following its therapeutic use at a marine Atlantic salmon farm. Aquaculture 1997;149:175-81.

35. Penghua W, Pow-Seng Y, Lim TT. C-N-S tridoped TiO for photocatalytic degradation of tetracycline under visible-light irradiation. Appl Catal Gen 2011;399:252-61.

36. Chen YS, Zhang HB, Luo YM, Song J. Occurrence and assessment of veterinary antibiotics in swine manures: A case study in East China. Chin Sci Bull 2012;57:606-14.

37. Sarmah AK, Meyer MT, Boxall AB. A global perspective on the use, sales, exposure pathways, occurrence, fate and effects of veterinary antibiotics (VAs) in the environment. Chemosphere 2006;65:725-59.

38. Batt AL, Snow DD, Aga DS. Occurrence of sulphonamide antimicrobials in private water wells in Washington County, Idaho, USA. Chemosphere 2006;64:1963-71.

39. Wang B, Lv XL, Feng D, Xie LH, Zhang J, Li M, et al. Highly stable $\mathrm{Zr}$ (IV)-based metal-organic frameworks for the detection and removal of antibiotics and organic explosives in water. J Am Chem Soc 2016;138:6204-16

40. Naik L, Sharma R, Mann B, Lata K, Rajput YS, Nath BS. Rapid screening test for detection of oxytetracycline residues in milk using lateral flow assay. Food Chem 2017;219:85-92.

41. Fatta-Kassinos D, Meric S, Nikolaou A. Pharmaceutical residues in environmental waters and wastewater: Current state of knowledge and future research. Anal Bioanal Chem 2011;399:251-75.

42. Javid A, Mesdaghinia A, Nasseri S, Mahvi AH, Alimohammadi M, Gharibi H. Assessment of tetracycline contamination in surface and groundwater resources proximal to animal farming houses in Tehran, Iran. J Environ Health Sci Eng 2016;14:4.

43. Pazdro K, Borecka M, Siedlewicz G, Białk-Bielinska A, Step-Nowski P. Analysis of the residues of pharmaceuticals in marine environment: 
State-of-the-art, analytical problems and challenges. Curr Anal Chem 2016;12:202-26.

44. Siedlewicz G, Borecka M, Białk-Bielinska A, Sikora K, StepNowski P, Pazdro K. Determination of antibiotic residues in southern Baltic Sea sediments using a tandem solid-phase extraction and liquid chromatography coupled with tan-dem mass spectrometry. Oceanologia 2016;58:221-34

45. KPMG International. The Indian Pharmaceutical Industry: Collaboration for Growth. Amstelveen, Netherlands: KPMG International; 2006. p. $2-42$.

46. Subedi B, Balakrishna K, Sinha R, Yamashita N, Balasubramanian V, Kannan K. Mass loading and removal of pharmaceuticals and personal care products, including psychoactive and illicit drugs and artificial sweeteners, in five sewage treatment plants in India. J Environ Chem Eng 2015;3:2882-91

47. Akiba M, Senba H, Otagiri H, Prabhasankar V, Taniyasu S, Yamashita N, et al. Impact of wastewater from different sources on the prevalence of antimicrobial-resistant Escherichia coli in sewage treatment plants in South India. Ecotoxicol Environ Saf 2015;115:203-8.

48. Archana G, Dhodapakar R, Kumar A. Offline solid-phase extraction for preconcentration of pharmaceuticals and personal care products in environmental water and their simultaneous determination using the reversed phase high-performance liquid chromatography method. Environ Monit Assess 2016;188:512-22.

49. Klajn R. Tetracycline: Chemistry and Chemical Biology of Tetracyclines. Poland: Institute of Organic Chemistry; 2001.

50. Hash JH, Wishnick M, Miller PA. On the mode of action of the tetracycline antibiotics in Staphylococcus aureus. J Biol Chem 1964;239:2070-8.

51. Semenkov YP, Makarov EM, Makhno VI, Kirillov SV. Kinetic aspects of tetracycline action on the acceptor (A) site of Escherichia coli ribosomes. FEBS Lett 1982;144:125-9.

52. Yamaguchi A, Udagawa T, Sawai T. Transport of divalent cations with tetracycline as mediated by the transposon Tn10-encoded tetracycline resistance protein. J Biol Chem 1990;265:4809-13.

53. Singh AK, Rathore G, Singh V, Mani I, Singh RK, Mishra SK. Bacterial resistance to oxytetracycline in different life stages of Indian freshwater carp aquaculture system. Int J Microbiol Res 2009;1:25-34.

54. Samanidou VF, Evaggelopoulou EN. Analytical strategies to determine antibiotic residues in fish. J Sep Sci 2007;30:2549-69.

55. Guardiola FA, Cerezuela R, Meseguer J, Esteban MA. Modulation of the immune parameters and expression of genes of gilthead seabream (Sparus aurata L.) by dietary administration of oxytetracycline. Aquaculture 2012;334-337:51-7.

56. Hentschel DM, Park KM, Cilenti L, Zervos AS, Drummond I, Bonventre JV. Acute renal failure in zebrafish: A novel system to study a complex disease. Am J Physiol Renal Physiol 2005;288:F923-9.

57. Santos LH, Araújo AN, Fachini A, Pena A, Delerue-Matos C, Montenegro MC. Ecotoxicological aspects related to the presence of pharmaceuticals in the aquatic environment. J Hazard Mater 2010;175:45-95.

58. Lionetto MG, Caricato R, Calisi A, Giordano ME, Schettino T. Acetylcholinesterase as a biomarker in environmental and occupational medicine: New insights and future perspectives. Bio Med Res Int 2013;321:1-8

59. Ren X, Wang Z, Gao B, Liu P, Li J. Toxic responses of swimming crab (Portunus trituberculatus) larvae exposed to environmentally realistic concentrations of oxytetracycline. Chemosphere 2017;173:563-71.

60. Limbu SM, Zhou L, Sun SX, Zhang ML, Du ZY. Chronic exposure to low environmental concentrations and legal aquaculture doses of antibiotics cause systemic adverse effects in Nile tilapia and provoke differential human health risk. Environ Int 2018;115:205-19.

61. Micale V, Pirrera L, Bottari T, Busalacchi B, Perdicihzzi A, Perdichizzi F, et al. A Multimarkers Approach to Assess the Environmental Pollution on Biological Resources Subject of Commercial fishing: The Case of Mullus barbatus (Linnaeus, 1758) in the Southern Tyrrhenian Sea. Italy: Marine Research at CNR, Fishery and Sea Resources; 2011. p. 2083-98.

62. Rodrigues S, Antunes SC, Correia AT, Nunes B. Rainbow trout (Oncorhynchus mykiss) pro-oxidant and genotoxic responses following acute and chronic exposure to the antibiotic oxytetracycline. Ecotoxicology 2017;26:104-17.

63. Kładna A, Michalska T, Berczyński P, Kruk I, Aboul-Enein HY. Evaluation of the antioxidant activity of tetracycline antibiotics in vitro. Luminecence 2012;27:249-54

64. Khan MA, Mustafa J, Musarrat J. Mechanism of DNA strand breakage induced by photosensitized tetracycline-Cu (II) complex. Mutat Res 2003;525:109-19.

65. Sara R, Sara CA, Bruno N, Teodorico CA. Histopathological effects in gills and liver of Sparusaurata following acute and chronic exposures to erythromycin and oxytetracycline. Environ Sci Pollut Res Int 2019;26:15481-95.

66. Botelho RG, Christofoletti CA, Correia JE, Ansoar Y, Olinda RA, Tornisielo VL. Genotoxic responses of juvenile tilapia (Oreochromis niloticus) exposed to florfenicol and oxytetracycline. Chemosphere 2015;132:206-12.

67. Said AA, Matsuki N, Kasuya Y. Effects of aminoglycoside antibiotics on cholinergic autonomic nervous transmission. Pharmacol Toxicol 1995;76:128-32.

68. Sharma M, Thakur J, Verma S, Sharma P. Cytotoxic and genotoxic effect of oxytetracyclin on fish Cyprinus carpio after acute exposure. Asian J Pharm Chem Res 2019;12:134-7.

69. Nazeri S, Farhangi M, Modarres S. The effect of different dietary inclusion levels of rutin (a flavonoid) on some liver enzyme activities and oxidative stress indices Fin rainbow trout, Oncorhynchus mykiss (Walbaum) exposed to oxytetracycline. Aquac Res 2017;48:4356-62.

70. Yonar ME, Yonar SM, Silici S. Protective effect of propolis against oxidative stress and immune suppression induced by oxytetracycline in rainbow trout (Oncorhynchus mykiss, W.). Fish Shellfish Immun 2011;31:318-25.

71. Liu J, Lu G, Cai Y, Wu D, Yan Z, Wang Y. Modulation of erythromycininduced biochemical responses in crucian carp by ketoconazole. Environ Sci Pollut Res Int 2017;24:5285-92.

72. Oliveira R, McDonough S, Ladewig JC, Soares AM, Nogueira AJ, Domingues I. Effects of oxytetracycline and amoxicillin on development and biomarkers activities of zebra fish (Danio rerio). Environ Toxicol Pharmacol 2013;36:903-12. 